\title{
THE CRITERION “COMPETENCE” IN THE ECONOMIC SECTOR
}

\author{
Venelin Terziev \\ Academician of the Russian Academy of Natural History, Moscow, Russia, Prof. D.Sc. (Ec.), D.Sc. \\ (National Security), D.Sc. (Social Activities), Ph.D., National Military University, Veliko Tarnovo, \\ Bulgaria; University of Rousse, Rousse, Bulgaria, terziev@skmat.com
}

\begin{abstract}
The article focuses on the presence of competence in the process of development of control in the economic sphere. For this purpose, the work of the social control mechanism is considered as a complex, material expression of the manifestations of the criterion competence system built on powers. Clarifying and specifying the role and place of the factor in question in the development of the control process predetermines the content of specific tasks involved with the theoretical economic and legal grounds that reveal the essential characteristic of the analyzed concept. In this context, the underlying argumentation is the following: the manifestaton and development of the competence factor creates the possibility, in general, of control and, in particular, of administrative control, to achieve high levels of efficiency.
\end{abstract}

Keywords: control, power, criterion.

\section{INTRODUCTION}

In the socio-economic sphere, deep and decisive transformations have been carried out both at home and globally. These are, in essence, attempts to optimize the operation of socially, economically and politically poor social systems in the last few years. Change and transformation processes are targeted actions to ignore identified deficits and create the conditions for a mechanism for the sustainable development of society, a mechanism called the "market" to function according to the laid expectations and the stated interests.

The establishment of different entities as both private and legal entities creates new meaning and content in the work of the state in regulating the requirements that they must meet at the entrance before entering into market and commercial relations. However, the legislative application of such state requirements to the behavior of the market players is pointless without control over their application and compliance. Analyses on the activity of the executive authority prove that the control issue is caused by the presence of certain key factors such as sometimes the catastrophic, dynamics of the socio-economic processes, the state of the legislation, the role of the state in protecting the interests declared by citizens and society, enhancing the statehood in addressing a number of recurrences of antisocial phenomena and corrupt practices.

\section{THE CRITERION “COMPETENCE” IN THE ECONOMIC SECTOR}

It is almost impossible to challenge the qualities of control as a social phenomenon. The history of the human race is the most significant proof and reason both for his manifestations and for his evolution. 
Regardless of the organization, the distinct types and the characteristic forms of expression, control is a public attitude, engaged in regulation of behavior, having a controlling influence both on personalities and on personal and social formations, which predetermines the analysis of the control both in theoretical and and in a purely practical-applied aspect. It is very delicate to assume whether these are two separate profiles or an official face of the publicly relevant impact under consideration.

Practically, the theory and practice with its various events complement and impose the perception of the control function in its entirety. The differences in behavior also provoke differences in the manifestations, and there is no doubt about the contradiction between the characteristics and the laws of public control, its methodology and its relation to social governance.

The theoretical developments and practical practices prove that exercising the control function is a highly moral power in the real application of professionalism and perfection in the behavior of individuals and their formations, which also acquires elements of creative activity due to the imposed adhocratic forms of organizational existence and freedom in the choice of behavioral models.

The analysis of control relations as a social phenomenon reveals great diversity in terms of their classification and types. The assignment of certain, considered relationships to a specific type takes place depending on the way of reconciling and exposing the differences of interests and potential of the social objects. The differences in interests present essential characteristics of specific, social organizational structures as well as the specifics of the periods of their development. It is this fact that specifies the varied, predominant purpose of critical relationships to certain aspects of behavior of social subjects and interests that provoke uncertainty.

In response to these critical aspects of behavior, areas with proven need for control are identified. Consumers of power resources motivated by their interests declare the critical boundaries of their behavior in these areas under established rules and norms.

The variations in the potentials of the social actors involved in the organizations have their own historical and actual specifics. The predominant sources of power may be different, establishing a certain range of opportunities for supremacy as dominating. Dominant opportunities for domination, in turn, predetermine the appropriate, most widely used ways of influencing the behavior of others by means of which the rules and norms are respected. Similarly to rules and norms, the means of influence and their compliance in some form are institutionalized. They become a mandatory part of the rules and norms.

The impact on individual behavior, its guiding in a certain direction, depending on certain criteria, norms and rules, is an objectively ongoing process of continuous striving for balanced correspondence between the subject and the object of control. Personalization and individualization do not alter relationships in this process except when the inclusion of behavior into the interests of a particular group is also a matter of deliberately manipulated within certain limits registered by specific interests. From the written so far, it can be concluded that the analysis of the specifics in the different stages of manifestation of ambiguity in the single control relation creates the conditions for typology of the attitude itself.

Each economic system can be considered as a set of interconnected production processes consisting of separate operations in which certain labor objects are transformed into consumption values. The unity of the processes and their forming operations is organized in a production-technological expedience, a proven necessity and a logical sequence of relations between them. The fact that the economic system is modeled by processes and operations - a specific expression of deliberate human activity, conveyed by relationships of individuals and their formations, defines it as a social organizational structure with a production-functional purpose.

The central problem in the analysis of social organization, regardless of its status and scale, is to what extent its organization and functioning effectively serve irrationally its socio-political or production-functional purpose. In order to solve it it is necessary for the systems management to monitor both the production and technological expedience of the processes and operations involved, as well as their social side, the effective structuring of the social relations, including the relations of control. In this sense, system management should take into account both the prduction and technological expedience of processes and operations and their social side.

At a certain stage in its development, society creates a governance structure and organization as its internal mechanism of action. Differences in individual socioeconomic formations are the result of altered ratios in the way of production and consumption, of contradictions expressed through the form of power and governance. The evolution of man is a result of the building and improvement of a particular structure of the society based on a certain way of objective, necessary, personal participation in a specific degree of the social production. 
The structure sets the dynamism, the moving part of social development and predetermines its real and potential opportunities for the realization of a certain goal.

In the management theory, it is known that the norm is a solution to the parameters in which the system is developed, its purpose and the objectives for each subsystem, each element and process. The control function is manifested not only to determine the performance of the norm but also to assess the quality of the decision. Here, it is worth noting that the norm is not a canon or dogma with a specific limiting character, but a precise expression of maximum satisfactory values of the decision taken, presenting its significance and potential.

Every norm, reflecting a specific management decision, is related to the reconciliation of a certain range of values of controllable and uncontrollable parameters. The classification of the parameters is implemented on the basis of the objective possibility the subject of the norm to influence them, and it is especially important to note that parameters uncotrollable for the specific norm influence its formulation too. When combining the controllable and uncontrollable parameters, a significant factor is defined for the specific norm, internal and external thresholds, called limitations on possible values of the parameters that characterize both their content and the relations between them.

In the process of forming the management solution, the possible outcomes are analyzed by linking to the values of the resultant parameters and forming several possible outcomes, providing conditions for fixing the selection criteria. The particular choice is related to the possibility of achieving desired values of the resultant parameters. It is necessary to have at least two variants of combinations of the parameters of the controllable parameters, leading to acceptable results for the decision subject.

The process of setting a norm for decision-making can be considered in two aspects, depending on the presence of control:

First, the control is about the reality of the chosen norm, its proper structural order of time and space, its adaptability to the system's capabilities, the correspondence with the best achievements in other systems. The assessment of the norm in the system from the positions of established criteria and requirements, of the leading achievements in the world becomes an objective development need, a mandatory condition for influence in control.

Second. The control assesses the presence of quantitative and qualitative dimensions in the norm, the precise characteristics of the controlled parameters. A norm in which time and space are absent, as well as the quantitative and qualitative dimensions, responsibilities and incentives, is beyond control. It deprives the management process of the normal development of rights and feedback, its nature and content. In this context, the purpose of control as a function of management is to ensure the implementation and updating of the assigned target function of the managed system on the basis of the feedback principle.

Against the backdrop of everything that is said in general about control, it should be added that the process of improvement enhances the presence of the society itself and the role of its leading controlling person in the state. It is precisely on this occasion that the administrative control, which is perceived as a specific form of control, is an immanent prerogative of the supreme state institution.

The analysis of this convergent control form proves that it has a sufficiently long history dating back to the 5 th century BC. With the codification of Roman law, it is considered that there is reason to speak of the first manifestations of such control. Whether and how exactly the next steps in its evolution are implemented is not so important, the essential point is that the state and the established subject in the face of the executive authority are actively involved in its formation. Conceptually, ideas arise related to: the police state, the bureaucratic organization, neoinstitutionalism and others.

By its nature, administrative control reveals that it is a government-managerial activity implemented through the performance of functions assigned to a body influencing the actions of different actors in public life. To complement the feature, it cannot be forgotten that administrative control is an essential part of the executiveordering activity of government.

Since the state administration itself is a legal, administrative, regulatory, organizational and controlling activity in all spheres of public life, in particular, the administrative control is established as the power of the executive authority.

The interesting and essential part of the analysis of the control exercised by the executive authority is the moment when the third reason related to the manifestation of competence is added to the grounds that are well known by the theory of control - as a critical public attitude and as a management function. The disclosure of the role of the third ground is a real opportunity through the theory of competence to clarify the 
administrative legal personality of the executive authority, in other words to specify the reason why only the structures of the executive power exercise this kind of control.

In Bulgarian legal literature, it is revealed that „competence means the authority the legislator has given to a particular person or place to make willed statements assigned to the state".

The administrative-legal science, specifically on the issue of competence,emphasizes on two thematic lines of development. One - "quantitative theory“ - explains competence as a distinct set. According to the other, competence is an expression of legal personality of the state body. In fact, the process of conferring authority on a particular body is a process of recognizing its ability to be constituted as a legal entity with a certain authority.

These understandings in recent years have influenced not only the development of administrative control itself, but also the overall presence and behavior of the state, especially in the processes of economic life. What's leading is that the state restricts its intervention in the development of business initiatives by the various actors. Its role is limited only to the administrative regulation in entering into legal relations on the basis of economic activity. Observing its interests, the state regulates the regulatory requirements that must be met by those wishing to enter the market.

The review of the legislative changes made over the last 10-15 years reveals that the supervisory competence of the authorities by the Bulgarian executive authority can be justified either as a manifestation of competence by level or separately and independently on the basis of a specific law. It is precisely the abovementioned finding that the representatives of the scientific circles, mainly lawyers, consider that on the occasion of the administrative control, the well-known "classical“ definitions of control should be used extremely carefully and precisely. The main recommendation for such actions is to emphasize the presence of "control competence" and the development of its essence and role (Georgiev, 2017a-b; Terziev, Stoyanov, Georgiev, 2017c-g; Dimitrovski, Pushova, Georgiev, 2017h-i; Terziev, Georgiev, 2017j-n; Banabakova, Georgiev, 2018a; Terziev, Nichev, Stoyanov, Georgiev, 2017o-q; Terziev, Nichev, Stoyanov, Georgiev, Bogdanov, 2017r; Terziev, Banabakova, Georgiev, 2018b-c; Bogdanova, 2018d; Bogdanova, 2017s; Bogdanova, 2016a; Bogdanova, 2015a; Bogdanova, 2011a).

\section{CONCLUSION}

The analyses and facts of the report allow us to conclude that competence, interpreted as a set of powers, is becoming a key factor in the development of control exercised by the state. Along with other established control sources or grounds, competence creates conditions in the implementation of control by the executive authority to eliminate certain established weaknesses and registered deficiencies.

\section{REFERENCE LIST}

Georgiev, Marin. (2017a). Sbalansirovannaya karta kak alyternativa malogo biznesa. // Innovatsionnie tehnologii $v$ nauke novogo vrmeni, Sbornik statey Mezhdunarodnoy nauchno - prakticheskoy konferentsii 1 fevralya 2017 g., Ufa NITS AETERNA, Chasty 1, 2017, s. 43-49, ISBN 978-5-00109004-5, ISBN 978-5-00109-007-6 (Георгиев, Марин. Сбалансированная карта как альтернатива малого бизнеса. // Инновационніе технологии в науке нового врмени, Сборник статей Международной научно - практической конференции 1 февраля 2017 г., Уфра НИЦ АЭТЕРНА, Часть 1, 2017, с. 43-49, ISBN 978-5-00109-004-5, ISBN 978-5-00109-007-6).

Georgiev, Marin. (2017b). The Role of the Balanced Scorecard as a tool of strategic management and control. // Journal of innovations and sustainability. Bulgaria, 3, 2017, N 2, pp. 31-63, ISSN 2367-8127 (CD-ROM), ISSN 2367-8151 (on-line).

Terziev, V., Stoyanov, E., Georgiev, M. (2017c). The factor information in the making of "the right" decision. // Scientific journal "ECONOMICS AND FINANCE». Publishing house "BREEZE», Current scientific research, Collection of scientific articles, Montreal, Canada, 2017, pp. 26-32, ISBN 978-617-7214-495.

Terziev, V., Stoyanov, E., Georgiev, M. (2017d). One solution for costs mini-manization in the banking sector. // Scientific journal «ECONOMICS AND FINANCE». Publishing house «BREEZE», Current scientific research, Collection of scientific articles, Montreal, Canada, 2017, pp. 62-66, ISBN 978-617- 
7214-49-5.

Terziev, V., Stoyanov, E., Georgiev, M. (2017e). Accountable regulation of foreign exchange operations. // Scientific journal «ECONOMICS AND FINANCE». Publishing house «BREEZE», Current scientific research, Collection of scientific articles, Montreal, Canada, 2017, pp. 66-71, ISBN 978-617-7214-495.

Terziev, V., Stoyanov, E., Georgiev, M. (2017f). Specifics of control in operations with precious metals and precious stones. // Scientific journal «ECONOMICS AND FINANCE». Publishing house «BREEZE», Current scientific research, Collection of scientific articles, Montreal, Canada, 2017, pp. 71-76, ISBN 978-617-7214-49-5.

Terziev, V., Stoyanov, E., Georgiev, M. (2017g). Intitutional team work -opportunity for improvement of financial control. // Scientific journal «ECONOMICS AND FINANCE». Publishing house "BREEZE», Current scientific research, Collection of scientific articles, Montreal, Canada, 2017, pp. 76-80, ISBN 978-617-7214-49-5.

Dimitrovski, R., Pushova, L., Georgiev, M. (2017h). The Balanced Scorecard Model as a tool for effective management. // International Journal of Scientific papers. Institute of Knowledge Management, Skopje, 17, 2017, N 2, pp. 1023-1027, ISSN 1857-923X (for e- version), ISSN 2545-4439 (for printed version).

Dimitrovski, R., Pushova, L., Georgiev, M. (2017i). The Balanced Scorecard Model as a tool for strategic management and control. // International Journal of Scientific papers. Institute of Knowledge Management, Skopje, 17, 2017, N 2, pp. 1035-1039, ISSN 1857-923X (for e- version), ISSN 25454439 (for printed version).

Terziev, V., Georgiev, M. (2017j). Highlights of the evolution of the 'Balanced Scorecard' idea as a model for managing strategy development and control. // SOCIOINT 2017- 4th In-ternational Conference on Education, Social Sciences and Humanities 10-12 July 2017- Du-bai, UAE, OCERINT- International Organization Center of Academic Research, 2017, pp. 607-610, ISBN: 978-605-82433-1-6.

Terziev, V., Georgiev, М. (2017к).Эволюция понимания аудита. // International Scientific and Practical Conference «Ukraine, Bulgaria, EU: Economic and social development trends» 11-12 september 2017, Prof. D-r Assen Zlatarov University - Burgas National University of Life and Environmental Sciences of Ukraine, 2017, c. 225-229, ISBN 978-619-160-821-8.

Terziev, V., Georgiev, М. (2017I). Концептуальные основы управленческого контроля - анализ и совершенствование (Kontseptualynaye osnovay upravlencheskogo kontrolya - analiz i sovershenstvovanie). // International Scientific and Practical Conference «Ukraine, Bulgaria, EU: Economic and social development trends» 11-12 september 2017, Prof. D-r Assen Zlatarov University - Burgas National University of Life and Environmental Sciences of Ukraine, 2017, c. 221-225, ISBN 978-619-160-821-8.

Terziev, V., Georgiev, M. (2017m). Функциональная характеристика и развитие идеи контроля (Funktsionalynaya harakteristika i razvitie idei kontrolya). // International Scientific and Practical Conference «Ukraine, Bulgaria, EU: Economic and social development trends» 11-12 september 2017, Prof. D-r Assen Zlatarov University - Burgas National University of Life and Environmental Sciences of Ukraine, 2017, c. 213-216, ISBN 978-619-160-821-8.

Terziev, V., Georgiev, M. (2017n). Формальные аудиторские проявления и институциональность (Formalynaye auditorskie proyavleniya i institutsionalynosty). // International Scientific and Practical Conference «Ukraine, Bulgaria, EU: Economic and social development trends» 11-12 september 2017, Prof. D-r Assen Zlatarov University - Burgas National University of Life and Environ-mental Sciences of Ukraine, 2017, c. 217-221, ISBN 978-619-160-821-8.

Banabakova, V., Georgiev, M. (2018a). The role of the Balanced Scorecard as a tool of strategic management and control. // Proceedings of INTCESS2018- 5th In-ternational Conference on Education and Social Sciences 5-7 February 2018- Istanbul, Turkey, International Organization Center of Academic Research, www.ocerints.org, Istanbul, Turkey, 2018, pp. 468-483, ISBN : 978-60582433-2-3.

Terziev, V., Nichev, N., Stoyanov, E., Georgiev, M. (20170). Key aspects of the problems of administrative control in Bulgaria. // Proceedings of ADVED 2017- 3rd International Conference on Advances in Education and Social Sciences 9-11 October 2017- Istanbul, Turkey. International Organization Center of Academic Research, www.ocerint.org, 2017, pp. 707-710, ISBN: 978-605-82433-0-9. 
IJASOS- International E-Journal of Advances in Social Sciences, Vol. V, Issue 13, April 2019

Terziev, V., Nichev, N., Stoyanov, E., Georgiev, M. (2017p). On some of the blank points in the application of administrative control in Bulgaria. // Proceedings of ADVED 2017- 3rd International Conference on Advances in Education and Social Sciences 9-11 October 2017- Istanbul, Turkey. International Organization Center of Academic Research, www.ocerint.org, 2017, pp. 695-700, ISBN: 978-60582433-0-9.

Terziev, V., Nichev, N., Stoyanov, E., Georgiev, M. (2017q). A general principle of the development process of balanced scorecards as an instrument of control. // Proceedings of ADVED 2017- 3rd International Conference on Advances in Education and Social Sciences 9-11 October 2017- Istanbul, Turkey. International Organization Center of Academic Research, www.ocerint.org, 2017, pp. 690-694, .ISBN: 978-605-82433-0-9

Terziev, V., Nichev, N., Stoyanov, E., Georgiev, M., Bogdanov, P. (2017r). Opportunities for strategic development of small business in Bulgaria. // Proceedings of ADVED 2017- 3rd International Conference on Advances in Education and Social Sciences 9-11 October 2017- Istanbul, Turkey. International Organization Center of Academic Research, www.ocerint.org, 2017, pp. 701-706, ISBN: 978-605-82433-0-9.

Terziev, V., Banabakova, V., Georgiev, M. (2018b). Developing customer service standards. // The 24th International conference the knowledge-based organization, Land Forces Academy "Nicolae Balcescu", Sibiu-Romania, Vol. XXIV, No 2, 2018, pp. 117-122, ISSN 1843-682X, ISBN 978-973-153327-8.

Terziev, V., Banabakova, V., Georgiev, M. (2018c). Effective options for determining customer profitability. // The 24th International conference the knowledge-based organization, Land Forces Academy "Nicolae Balcescu", Sibiu-Romania, Vol. XXIV, No 2, 2018, pp. 123-128, ISSN 1843-682X, ISBN 978-973-153327-8.

Bogdanova, Margarita. (2018d). Policies and Instruments for Social Development. // Journal of Innovations and Sustainability, Plovdiv, Bulgaria, 4, 2018, 1, pp. 59-63, ISSN 2367-8127 (CD-ROM), ISSN 23678151 (ON-LINE).

Bogdanova, Margarita. (2017s). Prilozhenie na prostranstveniya analiz v regionalnite izsledvaniya. // Statistikata kato nauka i praktika - traditsii i savremenni izmereniya: Sbornik s dokladi ot nauchnoprakticheska konferentsiya - Svishtov, 20 oktomvri 2017 g., Al Tsenov, 2017, str. 70-76, ISBN: 978954-23-1371-7 (Богданова, Маргарита. Приложение на пространствения анализ в регионалните изследвания. // Статистиката като наука и практика - традиции и съвременни измерения: Сборник с доклади от научно-практическа конференция - Свищов, 20 октомври 2017 г.АИ Ценов, 2017, стр. 70-76, ISBN: 978-954-23-1371-7).

Bogdanova, Margarita. (2016a). Tsentrovete za varhovi postizheniya i za kompetentnost - politiki i podhodi za upravlenie. // Sbornik dokladi ot Godishna universitetska nauchna konferentsiya: Nauchno napravlenie "Sotsialni, stopanski i pravni nauki“- Veliko Tarnovo, 20-21 oktomvri 2016 g. Veliko Tarnovo, NVU - Izd. kompleks, 7, 2016, str. 38-56, ISSN 1314-1937 (Богданова, Маргарита. Центровете за върхови постижения и за компетентност - политики и подходи за управление. // Сборник доклади от Годишна университетска научна конфреренция: Научно направление „Социални, стопански и правни науки“ - Велико Търново, 20-21 октомври 2016г. Велико Търново, НВУ - Изд. комплекс , 7, 2016, стр. 38-56, ISSN 1314-1937).

Bogdanova, Margarita. (2015a). The stakeholders in the planning process - a network approach to analysis. // Evropeyski praktiki i natsionalni refleksii v planiraneto: Mezhdunarodna yubileyna nauchnoprakticheska konferentsiya: Sbornik s rezyumeta - Svishtov, 24-25 april 2015 g., Al Tsenov, 2015, str. 37-39, ISBN: 978-954-23-1058-7 (Bogdanova, Margarita. The stakeholders in the planning process - a network approach to analysis. // Европейски практики и национални рефлексии в планирането: Международна юбилейна научно-практическа конференция: Сборник с резюмета - Свищов, 2425 април 2015 г., АИ Ценов, 2015, стр. 37-39, ISBN: 978-954-23-1058-7).

Bogdanova, Margarita. (2011a). Predizvikatelstva pred regionalnoto planirane v Balgariya. // Ikonomikata i upravlenieto $v$ XXI vek - resheniya za stabilnost $\mathrm{i}$ rastezh: Mezhdunarodna yubileyna nauchna konferentsiya - Svishtov, 8-9. noemvri 2011g.: Sbornik- dokladi, Al Tsenov, 2011, str. 282-286, ISBN: 978-954-23-0679-5 (Богданова, Маргарита. Предизвикателства пред регионалното планиране в България. // Икономиката и управлението в XXI век - решения за стабилност и растеж: Международна юбилейна научна конференция - Свищов, 8-9. ноември 2011г.: Сборникдоклади, АИ Ценов, 2011, стр. 282-286, ISBN: 978-954-23-0679-5). 